\title{
Danger of HeXavalent Chromium AND STRATEGY FOR THE REMEDITATION
}

\author{
${ }^{1}$ Aniruddha Roy, ${ }^{2}$ Ayan Das and ${ }^{3}$ Nirmal Paul \\ ${ }^{1,2,3}$ Global Institute of Management \& Technology, Krishnagar, Nadia, West \\ Bengal, PIN-741102 \\ ${ }^{1}$ aniruddha.rick@yahoo.com, \\ ${ }^{2}$ das.ayan 4 @gmail. com\& ${ }^{3}$ paul.nirmal 7@gmail.com
}

\begin{abstract}
Some metals as micronutrients have a major role in the life and growth process of plants and animals. However, certain forms of some metals may also act as toxic material even in relatively small quantities. Chromium is such a metal, whose concentration above a certain limit may cause a serious problem to the health of living organisms. Chromium (Cr) may occur in several chemical forms in organic and inorganic systems. In biological systems only $\mathrm{Cr}$ (III) and $\mathrm{Cr}$ (VI) are significant. Among these two states, trivalent chromium (Cr-III) is considered as an essential component, while hexavalent Chromium (Cr-VI) in biological system has been detected as responsible for so many diseases, even some specific forms of cancer. This paper intends to present the adverse effect of $\mathrm{Cr}(\mathrm{VI})$ on environment as well as on human beings and also try to find a way out to dissolve the problem by a newly developed efficient and cost effective technique.
\end{abstract}

\section{KEYWORDS}

Heavy Metals, Chromium, Trivalent Chromium, Hexavalent Chromium, Toxicological Effects, Mutagenic Effects, $\mathrm{Cr}(\mathrm{VI})$ Reduction.

\section{INTRODUCTION}

In the environment metals occur naturally in varying concentrations and are present in rock, soil, water, even in plants and animals. If the concentration levels of required metals in the living organisms are above certain limit, there must be some negative impact on them because in that case metals may easily be accumulated in the food chain of biosphere.

Cadmium, mercury, lead, copper, zinc, chromium are the heavy metals which have received special attentions in ecotoxicology in the recent years even though some of these metals are necessary for the biological function of organism. These metals may occur in different forms, such as- as ions in water, as vapor in air or as salt in metal rock, sand and soil. These may be bound by organic or inorganic molecules or attached to particles present in the air. Both natural and anthropogenic sources emit metals into the environment [1].

Once emitted, metals may reside in the environment for hundreds of years or more. Human activities have drastically changed the biogeochemical cycles and balance of some heavy metals

Rupak Bhattacharyya et al. (Eds) : ACER 2013,

pp. 485-496, 2013. @ CS \& IT-CSCP 2013

DOI : 10.5121/csit.2013.3245 
in the environments. Therefore, a tendency towards their accumulations in the soil, sea water, fresh water and sediments is observed. During the last three decades considerable attention has been given to the problems which are created due to the adverse effects of some heavy metals on various ecosystems in different environmental compartments. Numerous field observations indicate a significant increase of heavy metal concentrations in agricultural and forest soil as well as in marine and inland water sediments. This increase is frequently observed in remote areas; even those are thousands of kilometers away from the major anthropogenic sources. This is mainly because due to the spreading of these heavy metals by flow of underground water due to hydraulic gradient, flow of air or other transboundary atmospheric long range transport systems.

To access the ecological conditions and health risks associated with atmospheric fluxes of heavy metals, it is required to understand the relationship between sources of emission of these metals to the atmosphere and the levels of the concentrations of them in surrounding air and precipitate. In order to estimate the risk caused by metal pollution correctly, it is important to know the bioavailability of different chemical forms of the metals. Several heavy metals are more available when these are present in organometallic complexes (e.g. dimethyl mercury, tetra ethyl lead etc.) than as inorganic ions [2].

Chromium is one of the heavy metals, whose concentration in the environment is still increasing. Chromium (Cr) is most commonly found as trivalent state in nature. Hexavallent chromium compounds are also found in small quantities. Chromites $\left(\mathrm{Cr}_{2} \mathrm{O}_{3}, \mathrm{FeO}\right)$ is only ore, which contains a significant amount of chromium. It has been detected that $\mathrm{Cr}$ (III) is 100 times less toxic and 1000 times less mutagenic than $\mathrm{Cr}(\mathrm{VI})$. There has been an increasing demand for chromites ore in recent years. In the opencast mining process, the chromitesore, in the chromites ore processing industries like ferrochrome plant, chromites ore concentrating plant- chromites ore processing waste as well as waste rock materials are dumped in the open ground without considering the environmental impact. This results oxidation of $\mathrm{Cr}$ (III) to $\mathrm{Cr}$ (VI)which cause danger to the topography of the area. This also results leaching of Chromium (VI) and other impurities to the ground water as well as surface water bodies. Therefore, contamination of $\mathrm{Cr}$ in ground water, surface water, and soil, in the vicinity of mines and chromites ore processing industries is expected. Most significant impact due to chrome contamination is observed in the hydro sphere and which is increasing day by day. Chromium concentrations in the rivers and fresh water lakes range commonly between 1.0 and $10.0 \mu \mathrm{g} / \mathrm{L}$, in ocean water between 0.1 and $5.0 \mu \mathrm{g} / \mathrm{L}$. It has been estimated that about $6.7 \times 10^{6} \mathrm{~kg}$ of chromium flowing annually in the sea with the industrial waste effluents [3].

\section{SOURCES AND USES OF CHROMIUM}

Chromites ore $\left(\mathrm{Cr}_{2} \mathrm{O}_{3}, \mathrm{FeO}\right)$ is considered as the main source of chromium, which contains significant amounts of chromium in trivalent state. Hexavalent chromium is also found in a very small quantity in this ore. The ore is obtained from open cast mines, this is not been found in pure form, its highest grade contains about $55 \%$ chromic oxide.

Chromium and its compounds are useful in common life. Ferrochrome is the alloy, which is the main product of chromites ore. Ferrochrome is used to produce steel. Potassium chromate, sodium chromate and dichromate are among the other most important chromium products, which are mainly used for manufacturing chromic acid, chromium pigments for paint, ink, textile industries, in lather tanning and for corrosion control. Chromites ore is also used in refractory industry to make bricks, mortar etc. as, chromites has the ability to enhance thermal shock 
resistance, volume stability and strength of the material [4]. The other applications of chromium compounds include production of medicines, chemicals for laboratory use etc.

\section{ROUTES OF EXPOSURE}

Environmental concentration of chromium is known to increase due to industrial development. Two ionic forms of chromium, $\mathrm{Cr}$ (III) and $\mathrm{Cr}$ (VI)are present in various forms in soil, water and in the biota. Chromium and its compounds originate in the environment mainly from anthropogenic activities. Further in plants, soil and in the water, chemical equilibrium between different chromium forms may exists. The atmosphere has become a major pathway for long range transfer of chromium to different ecosystems [5]. The routes of exposure of chromium (VI) for human beings are thus different atmospheric segmentsas well as food.

\subsection{AIR}

The bronchial tree is the primary target organ for carcinogenic effects of chromium (VI). Inhalation of chromium containing aerosols is therefore a major concern with respect to exposure to chromium compounds. The retention of chromium compounds from inhalation based on a 24 hours respiratory volume of $20 \mathrm{~m}^{3}$ in urban areas with an average chromium concentration of 50 $\mathrm{mg} / \mathrm{m}^{3}$ is about 3-400 mg. Individual uptake may vary depending on other relevant factors e.g. tobacco smoking and on the distribution of particle sizes in the inhaled aerosol. Chromium has been detected as a component of cigarette tobacco and its concentration varying from 0.24-0.63 $\mathrm{mg} / \mathrm{kg}$ [6]. However, no clear information is available about the fraction of chromium that appears in main stream tobacco smoke.

\subsection{DRINKING WATER}

The efficient absorption of metals by soil tends to limit the effects of atmospheric input of chromium. The dumping of industrial waste materials significantly increase chromium concentration in soil and is usually accompanied by surface and underground water contamination. Hexavalent chromium is known as the most mobile chromium form in the soil as well as in water systems. Chromium (III) is generally not transported over great distance because of its low solubility and also tendency to be adsorbed by solid particles in the appropriate $\mathrm{pH}$ range. Redox conversion of $\mathrm{Cr}$ (III) to $\mathrm{Cr}$ (VI) may also happen in presence of oxygen in air, which increases the chromium (VI) dislocation from the soil into the water systems. Thus, the concentration of chromium in water varies according to the type of surrounding industrial sources and the nature of the underlying soil. It is quite natural consequence that, the increase of $\mathrm{Cr}(\mathrm{VI})$ concentration in water systems also increases $\mathrm{Cr}(\mathrm{VI})$ intake within the biosphere.

\subsection{FOOD}

The daily chromium intake from food is difficult to assess because, studies have used methods that are not easily comparable. The chromium intake alsodepends on the diets of concern area or concern person [7].

Levels of daily chromium intake from different routes of exposure are shown in table-1. 
Table-1: Levels of daily chromium intake from different routes of exposure.

\begin{tabular}{|c|c|c|}
\hline Routes of exposure & Daily intake & Absorption \\
\hline Food stuff & $<200 \mu \mathrm{g}$ & $<10 \mu \mathrm{g}$ \\
\hline Drinking water & $0.8-16 \mu \mathrm{g}$ & $<1 \mu \mathrm{g}$ \\
\hline Ambient air & $<1000 \mathrm{ng}$ & $<5 \mathrm{ng}$ \\
\hline
\end{tabular}

\section{Effects of Hexavalent Chromium on Human}

\subsection{TOXICOLOGICAL EFFECTS}

Severe and often deadly pathological changes are associated with excessive intake of Cr (VI) compounds. Cr (VI) has major toxic effects on biological systems. It has been found that occupational exposure to hexavalent chromium compound leads to a variety of clinical problems. Inhalation and retention of materials containing $\mathrm{Cr}$ (VI) can cause various health problems. Ulcers, perforation of nasal septum, acute irritating dermatitis, asthma,bronchitis, inflammation of larynx and liver have been recorded due to the exposure to $\mathrm{Cr}(\mathrm{VI})$ compounds. Skin contact of hexavalent chromium compounds can induce skin allergies.Cr(VI) compounds are irritating and corrosive when allowed to come with contact with skin,digestive systems or lungs [8].

Long term occupational exposure of hexavalent chromium (e.g. a worker in chromate industry) may cause severe damage to bronchial system. Epidemiological study on workers, working at the chromate industry shows a large increase in bronchogenic carcinomas among workers who are mainly involved in the isolation and manufacture process of dichromate from ores.

Necrosis of kidney has also been reported. Starting with tubular necrosis, diffuse necrosis of liver and subsequent loss of shape of kidney as well as, liver has been detected. A number of reports on human ingestion of $\mathrm{Cr}$ (VI) compounds have been found where major gastrointestinal bleeding from ulcerations of intestinal mucosa with cardiovascular shock is the ultimate result.

\subsection{Mutagenic ANd CaRCinOgenic EFFeCtS}

Mutagenic and carcinogenic nature of $\mathrm{Cr}(\mathrm{VI})$ ion have been established long ago. Cancer was documented in a chrome exposed worker 100 years ago. The mechanism of cancer formation caused by $\mathrm{Cr}$ (VI) is not known for certain. However, it has been postulated that $\mathrm{Cr}$ (VI) binds to double bond stranded deoxyribonucleic acid (DNA), thus altering gene replication, repairment and duplication process, which ultimately tends towards cancer. Workers expose to $\mathrm{Cr}$ (VI) compounds in stainless steel welding, pigment production and other industrial occupation may suffer by various forms of cancer. So many data related to epidemiological effect of Cr (VI) compounds have been received and reviewed from the late 1940s onwards. Only some of these data are mentioned below:

Alwens and Jonas [9] reported 20 cases of lung cancer in workers producing dichromates in Frankfurt am Main, Germany. The mean time of exposure for the affected persons was found to be about 30 years. (The mean time may be defined as the time from first exposure till the development of cancer). 
Machle and Gergorius [10] observed 156 deaths in their study group of approximately 1445 workers recruited in seven major chromate producing plants in United States. There were 46 deaths from cancer, 32 were due to lung cancer.

In a study on dichromates production workers in England, Bidstrup and Case [11] found 12 lung cancer among local population and workers employed.

In a study of two groups of lung cancer hospital patient in United States, Baetjer [12] found a 28.6 fold excess risk in chromate production workers. Further documentation of lung cancer risk in chromate production workers was presented by Mancuso, Hueper [13] and Taylor [14].

Some studies have reported on the content of chromium in lung tissues in lung cancer patients with previous chromate exposure. However, none of the authors was successfully elucidating exposure- response relationship on the basis of such data.

It has been established after a long research that, these problems are not only restricted to chromate industry workers. During the process of production a relatively large quantity of chromium is also released to the atmosphere, earth, lakes, rivers and oceans. In soil and water the less toxic $\mathrm{Cr}$ (III) ions are oxidized to $\mathrm{Cr}$ (VI). It is generally assumed that in living organisms only the reduction process of $\mathrm{Cr}(\mathrm{VI})$ to $\mathrm{Cr}(\mathrm{III})$ takes place.

An interesting fundamental feature of chemistry of chromium (VI) ion is its redox behavior. The most important and known reason of the mutagenic activity of $\mathrm{Cr}$ (VI)is exactly the oxidation property of the ion.Cr (VI) ions are easily transported to the cellular membrane. Once the ions (Cr-VI) enter the cell, they oxidize its constituents and undergo a metabolic reduction, i.e. $\mathrm{Cr}(\mathrm{VI})$ is reduce to $\mathrm{Cr}$ (III). Ultimately migration to the nuclei of various chromium metabolite complexes and interaction with DNA cause the final negative effect.

\section{Analytical Method: Spectrophotometric Measurement Of Chromium(VI)}

Spectrophotometric measurement of Cr (VI) may be conducted by the following method. This method involves the steps stated below.

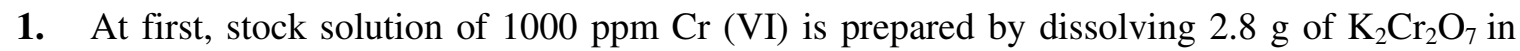
distilled water to $1000 \mathrm{ml}$ volume. A set of four standard solutions of $\mathrm{Cr}$ (VI) of **appropriate concentrations are prepared by diluting the stock solution.

2. To estimate $\mathrm{Cr}$ (VI) in water sample, direct sample is taken. To estimate total $\mathrm{Cr}(\mathrm{VI})$ in any type of solid waste(COPSW/chromites ore/soil) alkaline digestion of the sample is required to solubilize both water soluble as well as water insoluble $\mathrm{Cr}$ (VI), present in that sample. In this method $2.5 \pm 0.1 \mathrm{~g}$ of powdered sample $(0.065-0.074 \mathrm{~mm}$ size $)$ is digested using $50 \mathrm{ml}$ of alkaline solution $\left(0.28 \mathrm{M} \mathrm{Na}_{2} \mathrm{CO}_{3}\right.$ and $\left.0.5 \mathrm{M} \mathrm{NaOH}\right), 400 \mathrm{mg} \mathrm{MgCl}_{2}$ and $0.5 \mathrm{ml}$ of $1.0 \mathrm{M}$ phosphate buffer solution $\left(0.5 \mathrm{M} \mathrm{K}_{2} \mathrm{HPO}_{4}+0.5 \mathrm{M} \mathrm{KH}_{2} \mathrm{PO}_{4}\right)$ at $90-95^{\circ} \mathrm{C}$ for 1 hour. Then the mass is cooled to room temperature and filtered through $0.45 \mu \mathrm{m}$ membrane filter pad to 250 $\mathrm{ml}$ volumetric flask with proper washing. Finally, the $\mathrm{pH}$ of the filtrate is adjusted to $7.5 \pm 0.5$ by drop wise addition of $5.0 \mathrm{M} \mathrm{HNO}_{3}$ solution. The volume is made up to the mark.

3. Next, $50 \mathrm{ml}$ of filtrate is taken in a $100 \mathrm{ml}$ volumetric flask. $2 \mathrm{ml}$ of $0.2(\mathrm{~N}) \mathrm{H}_{2} \mathrm{SO}_{4}$ and $2 \mathrm{ml}$ of 1,5-diphenylcarbazide solution are added one by one. Then volume is made up to the 
mark and the solution is mixed thoroughly. The solution is kept for 10 minutes for the appearance of a red violet colour. Development of colour for the set of four standard solutions are performed in the same manner.

4. The absorbence of all solutions are measured at $540 \mathrm{~nm}$ wavelength by spectrophotometer. Then "-calibration curve is constructed by plotting absorbance value against concentration of standard solutions. The unknown concentration of the sample solution is obtained by putting its absorbance value in the calibration curve. However, in case of modern instrument calibration curve is constructed automatically and concentration of unknown solution is provided by the instrument directly.

5. Finally, the concentration of $\mathrm{Cr}$ (VI) in the parent sample (without dilution) is calculated by applying dilution factor. [Concentration of $\mathrm{Cr}(\mathrm{VI})$ in the parent sample $=$ Result obtained $\mathrm{X}$ Dilution factor.]

** This is to be noted that, the concentration of $\mathrm{Cr}(\mathrm{VI})$ in standard solution are to be chosen in such a way that, $\mathrm{Cr}$ (VI) concentration in the sample solution after final dilution, lies in between those of standards.

-- One set of experimental data is shown in table-2. Calibration curve for $\mathrm{Cr}$ (VI) is shown in Fig1, estimation of $\mathrm{Cr}(\mathrm{VI})$ in different type of samples is shown in Fig-2in the form of a flowchart.

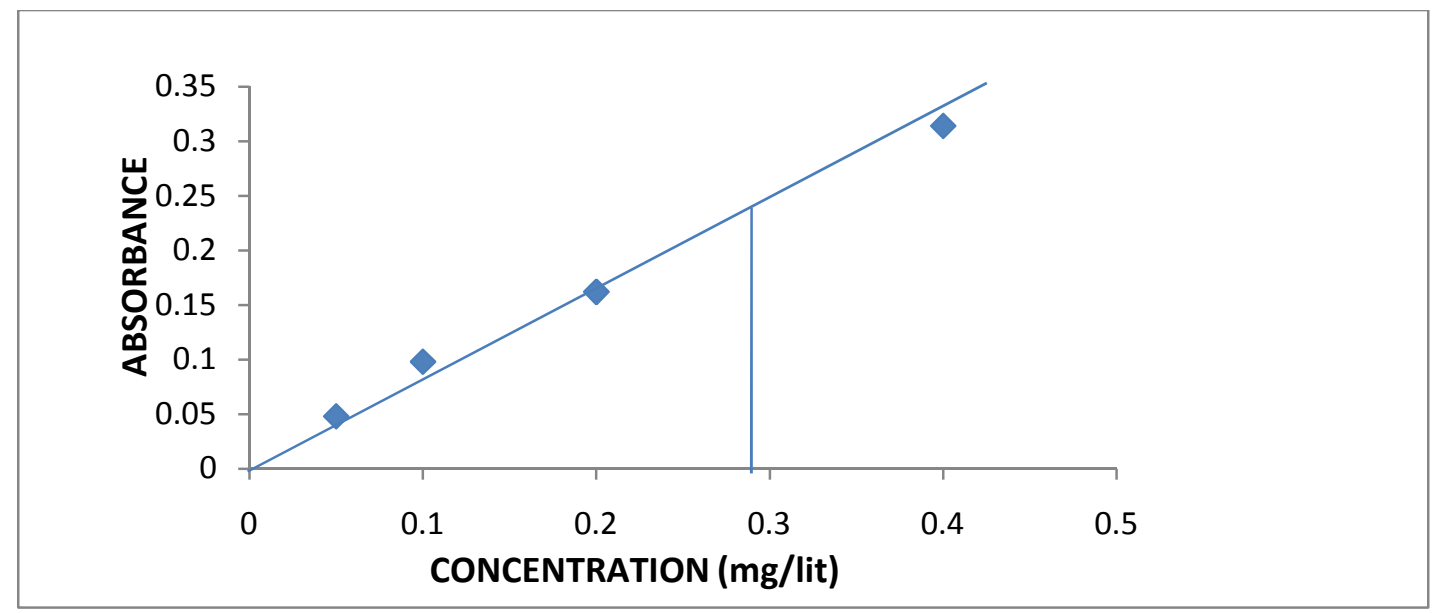

Fig-1: Calibration curve for $\mathrm{Cr}(\mathrm{VI})$ 


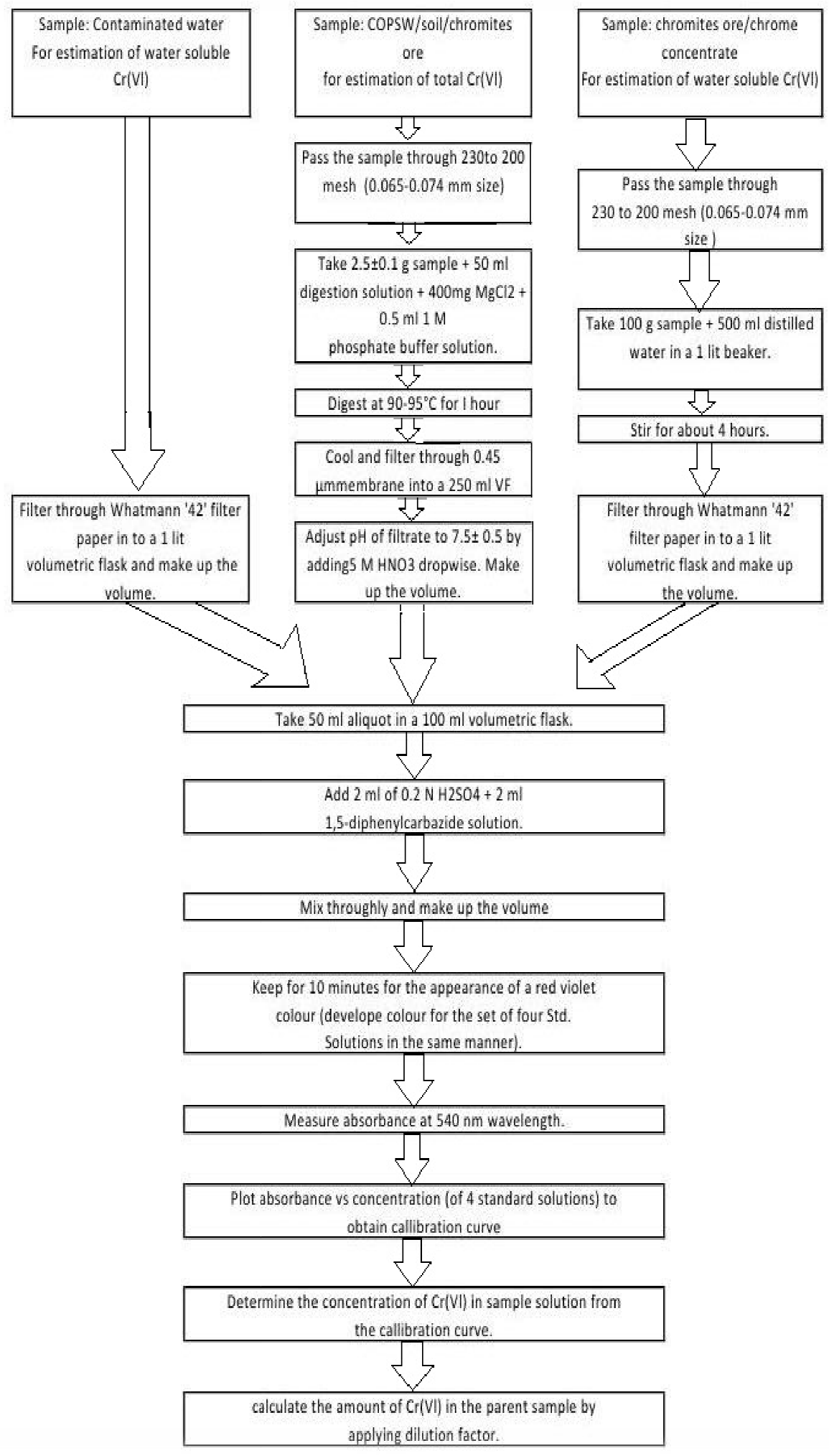

Fig-1: Flow Chart Diagram for estimation of $\mathrm{Cr}(\mathrm{VI})$ in different type of samples 
Table-2: Absorbance value of $\mathrm{Cr}$ (VI) solutions with different concentrations.

\begin{tabular}{|c|c|}
\hline Concentration (mg/lit) & Absorbance \\
\hline 0.05 & 0.048 \\
\hline 0.10 & 0.098 \\
\hline 0.20 & 0.162 \\
\hline 0.40 & 0.314 \\
\hline sample & 0.246 \\
\hline
\end{tabular}

- From the calibration curve [Fig-2] concentration of $\mathrm{Cr}$ (VI) in the sample is found to be $0.288 \mathrm{mg} / \mathrm{lit}$.

\section{Removal of Hexavalent Chromium by A New Technique}

To remove hexavalent chromium from its main sources like- chromites ore, chromites ore processing solid waste, surface or underground water, so many research works have been done in the recent years. One new technique in this regard has been invented by the author and his coworkers in GEO-CHEM LABORATORY, Bhubaneswar. This method is based on the reduction of hexavalent chromium to trivalent chromium by a reductant solution. This promising technique appears to be more effective and less expensive than other conventional physiochemical methods. This process may relieve the toxicity of chromium (VI) acting on living organisms by converting it to chromium (III), as it has been proved that, $\mathrm{Cr}$ (III) is 100 times less toxic and 1000 times less mutagenic than $\mathrm{Cr}(\mathrm{VI})$ as mentioned previously.

The main sources of Cr (VI) are chromites ore processing solid waste (COPSW), and chromites ore, which are obtained from different ferrochrome (an alloy which is used to produce steel) production plants and chromites ore mines respectively. This process is mainly based on removal of $\mathrm{Cr}$ (VI) from COPSW, consisting of slag, conditioning tower sludge and electrostatic precipitator dust of ferrochrome production plants. It has been estimated that, chromites ore processing solid waste contains $\mathrm{Cr}$ (VI) in a very high concentration. In COPSW, the amount of $\mathrm{Cr}$ (VI) as solid phase is found to be in the range of 200 to $600 \mathrm{mg} / \mathrm{kg}$ and that as dissolved phase is in the range of 10 to $55 \mathrm{mg} / \mathrm{kg}$. Chromium (VI), which is present as dissolved phase can be removed by proper washing of COPSW by ordinary water. However, removal of $\mathrm{Cr}$ (VI) as solid phase can't be possible by any physical treatment. This new method is capable of removing $\mathrm{Cr}$ (VI) present in COPSW as solid as well as dissolved phase.

In this method a solution of ferrous sulphate $\left(\mathrm{FeSO}_{4}\right)$ and sodium dithionite $\left(\mathrm{Na}_{2} \mathrm{~S}_{2} \mathrm{O}_{4}\right)$ is injected into the source to enhance the reduction of $\mathrm{Cr}$ (VI) to $\mathrm{Cr}$ (III). The solution of $\mathrm{FeSO}_{4}$ in combination with $\mathrm{Na}_{2} \mathrm{~S}_{2} \mathrm{O}_{4}$ also inhibit the oxidation and precipitation of ferrous ion. Laboratory batch tests using a $0.06 \mathrm{M} \mathrm{FeSO}_{4}+0.06 \mathrm{M} \mathrm{Na}_{2} \mathrm{~S}_{2} \mathrm{O}_{4}$ solution on COPSW indicate effective reduction of $\mathrm{Cr}(\mathrm{VI})$ both in solid and dissolved phase. It has been found that (Developed by trial and error method) $100 \mathrm{ml}$ of reductant solution is capable to completely remove (or reduce) hexavalent chromium from $2 \mathrm{~kg}$ of COPSW. A field (site) test involving injection (by spraying) of 1600 lit of $0.08 \mathrm{M} \mathrm{FeSO}_{4}+0.08 \mathrm{M} \mathrm{Na}_{2} \mathrm{~S}_{2} \mathrm{O}_{4}$ solution into a COPSW stack containing $30,000 \mathrm{~kg}$ material, has been performed. After the treatment, proper mixing the material has been done. Estimation of Cr (VI) in COPSW sample, which was collected uniformly (as per IS sample collection procedure) from the stack, showed that an effective reduction of $\mathrm{Cr}$ (VI) in the COPSW stack. Only trace of Cr (VI) (3 to 5 ppm) was detected. 
Although this method is based on removal of $\mathrm{Cr}(\mathrm{VI})$ from chromites ore processing solid waste, it may also be applicable for the removal of Chromium (VI) from other sources like chromites ore, underground and surface water. Removal of $\mathrm{Cr}$ (VI) from chromites ore can be done by the similar way as described for COPSW. For the treatment of Chromium (VI) contaminated water ( which are found in the area located near chromites ore mines or have high percentage of $\mathrm{Cr}_{2} \mathrm{O}_{3}$, $\mathrm{FeO}$ in its soil), after reduction, the precipitate $\left(\mathrm{Cr}_{2} \mathrm{O}_{3}, \mathrm{XH}_{2} \mathrm{O}\right)$ is to be removed by filtration. In all the cases, the dose ( concentration and quantity) of reductant solution are to be adjusted according to the concentration range of $\mathrm{Cr}(\mathrm{VI})$ in the source.

Table-3:Experimental results of laboratory batch tests.

\begin{tabular}{|c|c|c|c|c|c|}
\hline \multirow{2}{*}{$\begin{array}{c}\text { Sample } \\
\text { batch } \\
\text { no. }\end{array}$} & \multirow[b]{2}{*}{$\begin{array}{l}\text { Weight of } \\
\text { sample } \\
\text { taken for } \\
\text { treatment } \\
(\mathrm{kg})\end{array}$} & \multirow[b]{2}{*}{$\begin{array}{c}\text { Initial } \\
\text { concentration of } \\
\text { total } \mathrm{Cr}(\mathrm{Vl}) \\
\text { before treatment } \\
(\mathrm{mg} / \mathrm{kg})\end{array}$} & \multicolumn{2}{|c|}{ Dose of reductant solution } & \multirow[b]{2}{*}{$\begin{array}{c}\text { Final } \\
\text { concentration of } \\
\text { total } \mathrm{Cr}(\mathrm{Vl}) \text { after } \\
\text { treatment } \\
(\mathrm{mg} / \mathrm{kg})\end{array}$} \\
\hline & & & Volume(ml) & $\begin{array}{l}\text { Concentration } \\
\text { (M) }\end{array}$ & \\
\hline 1 & 2 & 442 & $100 *$ & 0.005 & 414 \\
\hline 2 & 2 & 445 & 100 & 0.010 & 374 \\
\hline 3 & 2 & 457 & 100 & 0.015 & 331 \\
\hline 4 & 2 & 460 & 100 & 0.020 & 296 \\
\hline 5 & 2 & 448 & 100 & 0.025 & 257 \\
\hline 6 & 2 & 447 & 100 & 0.030 & 223 \\
\hline 7 & 2 & 452 & 100 & 0.035 & 182 \\
\hline 8 & 2 & 456 & 100 & 0.040 & 147 \\
\hline 9 & 2 & 448 & 100 & 0.045 & 110 \\
\hline 10 & 2 & 443 & 100 & 0.050 & 72 \\
\hline 11 & 2 & 449 & 100 & 0.055 & 32 \\
\hline 12 & 2 & 451 & 100 & 0.060 & 3 \\
\hline 13 & 2 & 457 & 100 & 0.065 & 5 \\
\hline 14 & 2 & 450 & 100 & 0.070 & 4 \\
\hline 15 & 2 & 455 & 100 & 0.075 & 3 \\
\hline 16 & 2 & 446 & 100 & 0.080 & 4 \\
\hline 17 & 2 & 444 & 100 & 0.085 & 5 \\
\hline 18 & 2 & 453 & 100 & 0.090 & 3 \\
\hline 19 & 2 & 459 & 100 & 0.095 & 4 \\
\hline 20 & 2 & 445 & 100 & 0.100 & 5 \\
\hline
\end{tabular}

*This has been observed that at least $100 \mathrm{ml}$ reductant solution is required to moisten $2 \mathrm{~kg}$ sample properly. 


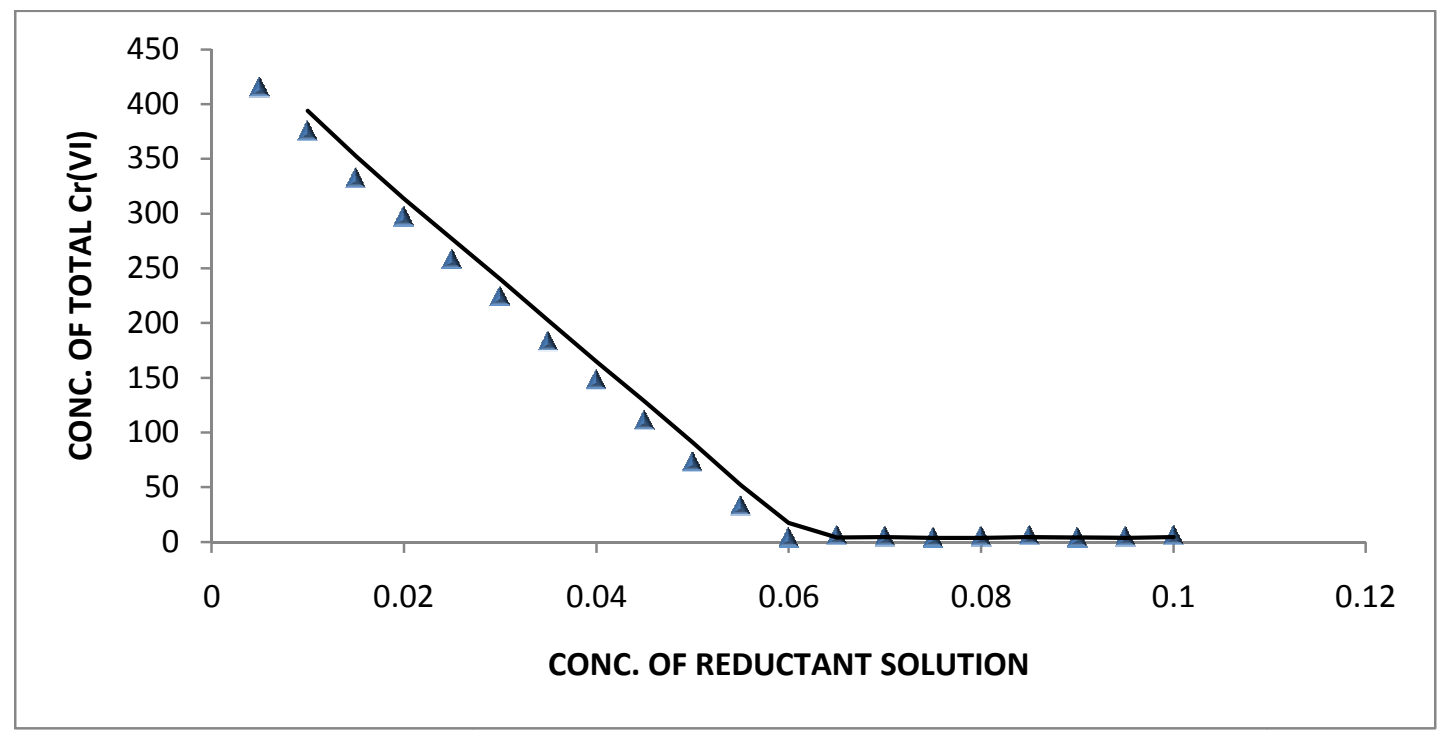

Fig-3: Plot of concentration of residual Cr(VI) vs. Concentration of reductant solution

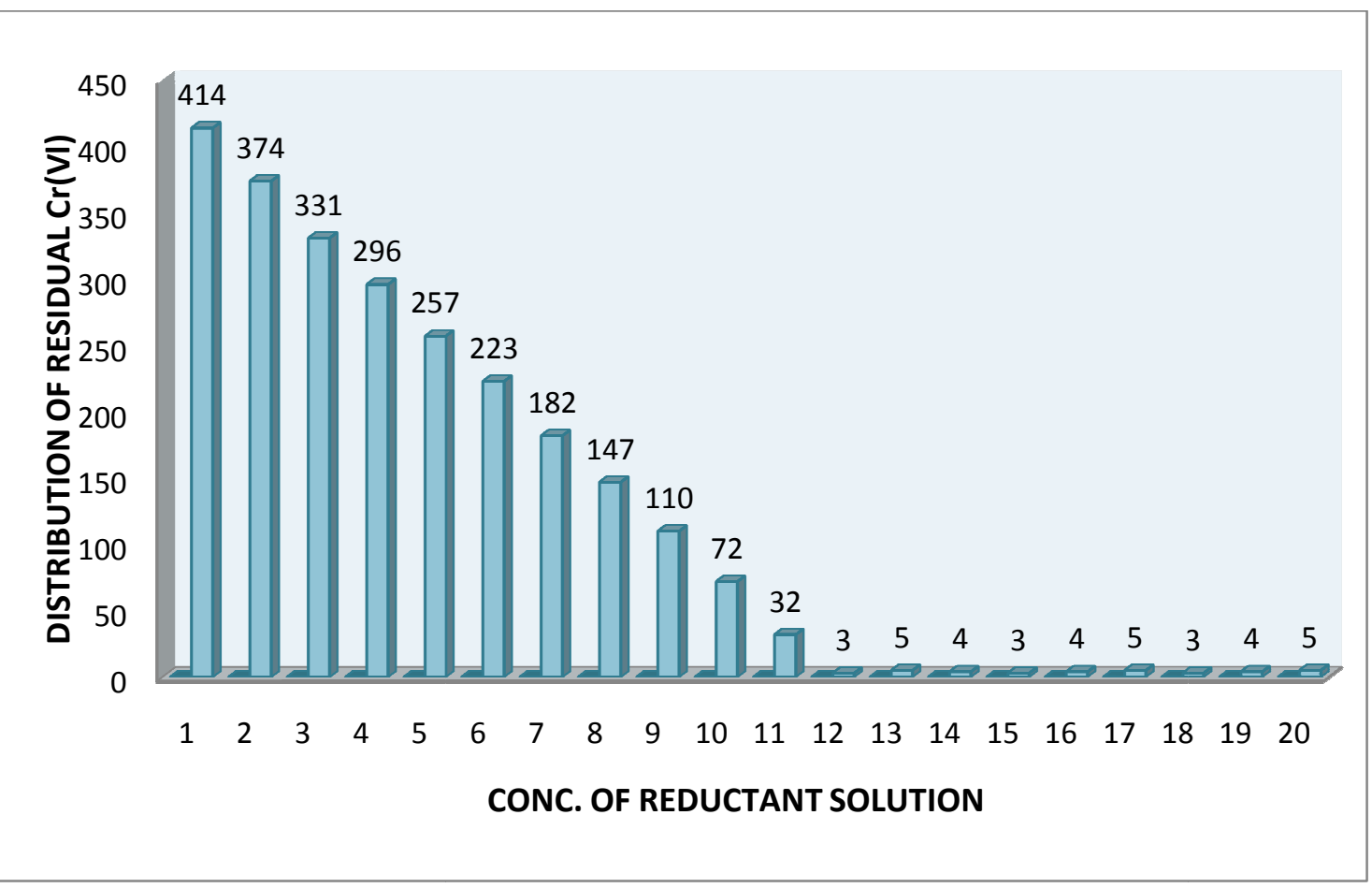

Fig-4: Distribution of residual Cr (VI) in samples after treatment with reductant solutions with different Conclusion:

It may be concluded that hexavalent chromium above certain limit in mine discharge, soil or ground water has an adverse effect on environment as well as on living beings whereas trivalent 
chromium is thought to be necessary for the normal functioning of living organisms. However, the necessity of chromium (III) may still be a controversial subject. Some laboratory studies have also shown that trivalent chromium may cause allergy. Some of the $\mathrm{Cr}$ (III) compounds are toxic, even genotoxic for human. Moreover, the oxidation of $\mathrm{Cr}$ (III) to $\mathrm{Cr}$ (VI) is very common process due to arial oxidation. So, more research works are also needed to reveal the actual impact of trivalent chromium on biosphere or mainly on human beings.

\section{ACKNOWLEDGEMENT:}

The authors gratefully acknowledge the necessary support and assistance provided by GEOCHEM LABORATORY, Bhubaneswar, Orissa during this study. Mr. Asit Kr. Roy, Ex. Assistant Professor in Chemistry, GIMT, Krishnagar and Dr. Rupak Bhattacharyya, HOD, AS\&H Department, GIMT, Krishnagar, deserve special thanks from the authors for their valuable suggestions during the process of development of this paper.

\section{REFERENCE:}

[1] Kihlstrom J.E, Toxicology- the environmental impact of pollutants, Abo Akademi University, Baltic University programme, Uppsala, (1992)

[2] Ziolkowski J., Environmental chemistry Protection, Education in advanced chemistry, Vol. 3, Poznan- Wroclaw.(1996)

[3] A. Bielicka, I. Bojanowska, A. Wisniewski : Two Faces of Chromium -Pollutant and Bioelement. Polish Journal of Environmental studies Vol. 14, No. 1,5-10, (2005)

[4] Ullmann's Encyclopedia of Industrial Chemistry, Vol. A 7,Chromium and Chromium Alloys, Germany (1986)

[5] Kendrickm.J., May M.T., Plishkam.J., Robinson K.D., Metals in biological systems, Ellis Horwood Limited. (1992)

[6] Chromium, Nickel and Welding. Lyon, International Agency for research on cancer, pp. 463-474 (IARC Monographs on the Evaluation of Carcinogenic Risk of Chemicals to Humans, Vol. 49,(1990)

[7] Health assessment document for chromium. Research Triangle Park, NC, United States Environmental Protection Agency, (1984).[Final report No. EPA 600/8-83-014F].

[8] Cieslak- Golonka M., Chromium compounds in the systems of biological importance (In Polish ), Wiadomosci chemiczne 48 (1-2), 59, 1994

[9] Alwens,W., Gonas, W. Der chromate- Lungenkrebs [lung cancer caused by chromate]. Acta unionis internationals contra cancrum,3:103-118(1938).

[10] Machle,W. \& Gregorius,F. Cancer of the respiratory system in the United States Chromateproducing industry. Public health reports, 63:1114-1127(1948).

[11] Bidstrup, P. L. \& Case, R. A. M. Carcinoma of the lung in workmen in the bichromates - producing industry in Great Britain. British journal of industrial medicine, 13:260-264(1956).

[12] Bactjer, A.M. Pulmonary carcinoma in chromate workers. I. A. review of the literature and reports of cases, AMA archives of industrial hygiene and occupational medicine, 2:487-504(1950).

[13] Mancuso, T.F. \& Hueper, W.S. Occupational cancer and other health hazards in a chromate plant: A medical appraisal. I. Lungs cancer in chromate workers. Industrial medicine and surgery, 20:358-363 (1951).

[14] Taylor F. H. The relationship of mortality and duration of employment as reflected by a cohort of chromates workers, American journal of public health, 56:218-229(1966). 


\section{AUTHORS:}

Aniruddha Roy has been working as an assistant professor in Chemistry under Applied Science \& Humanities Department in Global Institute of Management \& Technology, Krishnagar, West Bengal. He had worked as quality controller, senior chemist, Lab in charge in different multinational companies for more than 14 years. He worked in Orissa belt for more than 8 years, where he developed some new techniques on mineral analysis for his company. The method published in this paper was also developed by him during that period of time. He guided some ferrochrome production plants in Orissa to follow this technique in order to avoid the pollution from hexavalent chromium.

Nirmal Paul has been working as a Technical Assistant in Chemistry under the Department of Applied Science and Humanities in Global Institute of Management \& Technology, Krishnagar, Nadia, West Bengal.

Ayan Das has been working as an assistant professor in Chemistry under the Department of Applied Science and Humanities in Global Institute of Management \& Technology, Krishnagar, Nadia, West Bengal. He possesses 5 years teaching experience at college level.
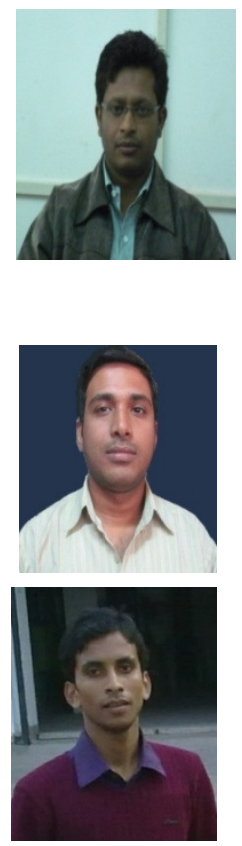